\title{
THE ESTUARINE VERSION OF THE COLHEAT DIGITAL SIMULATION MODEL
}

\author{
D. G. Daniels
}

J. C. Sonnichsen

R. T. Jaske

June 1970

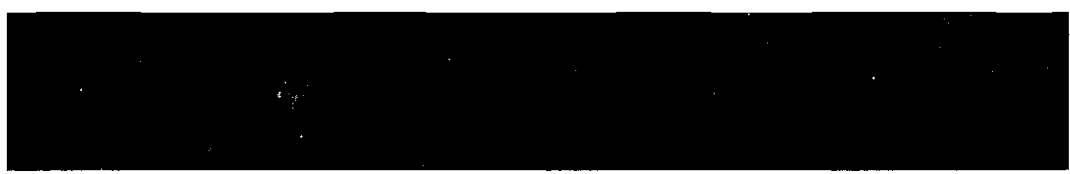

\section{AEC RESEARCH \& DEVELOPMENT REPORT}




\section{LEGAL NOTICE}

This report was prepared as an account of Government sponsored work. Neither the United States; nor the Commission, nor any person acting on behalf of the Commission:

A. Makes any warranty or representation, expressed or implied, with respect to the accuracy, completeness, or usefulness of the information contained in this report, or that the use of any information, apparatus, method, or process disclosed in this report may not infringe privately owned rights; or

B. Assumes any liabilities with respect to the use of, or for damages resulting from the use of any information, apparatus, method, or process disclosed in this report.

As used in the above, "person acting on behalf of the Commission" includes any employee or contractor of the Commission, or employee of such contractor, to the extent that such employee or contractor of the Commission, or employee of such contractor prepares, disseminates, or provides access to, any information pursuant to his employment or contract with the Commission, or his employment with such contractor.

\section{PACIFIC NORTHWEST LABORATORY}

RICHLAND, WASHINGTON

operated by

BATTELLE MEMORIAL INSTITUTE

for the

UNITED STATES ATOMIC ENERGY COMMISSION UNDER CONTRACT AT(45-1)-1830 
BNWL -1342

UC-70, Waste Disposal and Processing

THE ESTUARINE VERSION OF THE COLHEAT DIGITAL SIMULATION MODEL

D. G. Daniels

J. C. Sonnichsen

R. T. Jaske

Water and Land Resources Department Environmental and Life Sciences Division

June 1970

BATTELLE MEMORIAL INSTITUTE

PACIFIC NORTHWEST LABORATORIES

RICHLAND, WASHINGTON 99352 


\section{THE ESTUARINE VERSION OF THE COLHEAT DIGITAL SIMULATION MODEL \\ D. G. Daniels, J. C. Sonnichsen and R. T. Jaske \\ ABSTRACT}

The COLHEAT simulation model, developed jointly on Division of Production and Division of Reactor Development and Technology funds for the Atomic Energy Commission, was modified to simulate spatial and temporal variations of temperature, chemical, and radionuclide concentration above the salt intrusion in coastal plain estuaries where the river flow is dominant. This report explains these modifications and describes a case study on the Columbia River estuary. Funding for the case study was provided by Clark and Cowlitz County Public Utility Districts. 
BNWL -1342

\section{FOREWORD}

The number of power plants operating along the estuaries is increasing and projections based on the rate of increase suggest that many additional plants will have to be located along estuaries in order to meet the growing power demands of the future. Increasing the number of power plants along these waterways could have an adverse effect upon the ecological communities. As a result, the Division of Reactor Development and Technology authorized the development of a simulation model which could be used to estimate the effect of these power plants on the estuarine environment. The basic model was developed as a version of the COLHEAT river simulation model originally used for Division of Production work on the Columbia River. This report describes a simulation model for use above the zone of salt water intrusion where tidal fluctuations are still salient.

With the permission of Clark and Cowlitz County Public Utility Districts, the use of the estuarine version of COLHEAT is presented as a case study to relate the model to an actual siting problem currently receiving public attention. All work required to modify the program for use in the case study of the Kalama site was fully authorized under Contract AT(45-1)-1831. A separate report of this investigation was published for the Public Utility Districts and portions are included in this report for continuity. Requests for complete copies of the original report should be directed to the attention of R. W. McKinney, Cowlitz County Public Utility District, 960 Commerce Avenue, Longview, Washington, 98362 .

Further estuarine case studies have been authorized by the Division of Reactor Development and Technology under the program "Regional Modeling of Surface Water Temperatures from Projected Power Growth." These cases are still under investigation and will be reported separately as soon as they are completed. 


\section{CONTENTS}

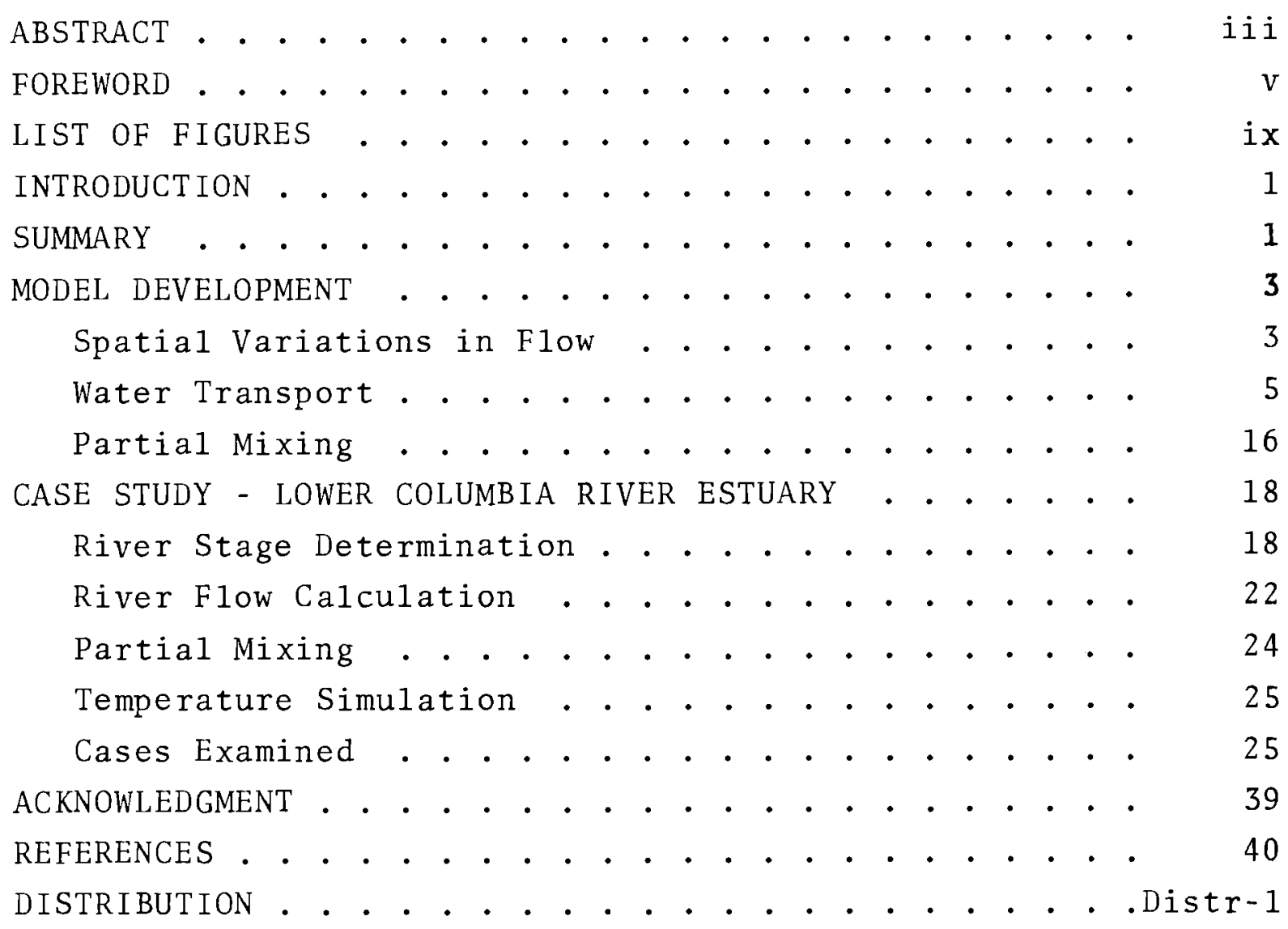




\section{LIST OF FIGURES}

1 Flow Through a Typical Estuarine River Section . . . . 4

2 Stage Flow Chart for Estuarine Version . . . . . . . 6

3 Flow Calculation Flow Chart for Estuarine Version . . . 7

4 Four Possible Cases for Water Transport . . . . . . . . 8

5 Flow Chart for Water Transport - Initiation for $n$

Trough Flow .................. 9

6 Flow Chart for Water Transport - - Mainstream and

Tributary Flow................ 10

7 Flow Chart for Water Transport - High Flow . . . . . 11

8 Flow Chart for Water Transport - - New River Section

Values . . . . . . . . . . . . . . . 12

9 Flow Chart for Water Transport - - Complete Normal Flow and Check for Reverse Flow . . . . . . . . . . 13

10 Flow Chart for Water Transport - - High Reverse Flow . . 14

11 Flow Chart for Water Transport -- Reverse F1ow -

River Section Values and Terminal Values . . . . . . 15

12 Partial Mixing Concept for Mixing in the Three-Trough Mode1 .................... 17

13 Structure of Executive Program for the Estuarine Version 19

14 Mean and Diurnal Stage Variation on the Lower Columbia

River ... . . . . . . . . . . . . 20

15 Time Lag for High and Low Water on the Lower Columbia

River Based on Tongue Point Tide . . . . . . . . 21

16 U.S.G.S. River Flows at Beaver Compared with River Flows

Predicted by the Estuarine Version at Beaver . . . . 23

17 Lower Columbia River Temperature Simulation . . . . . 26

18 Lower Columbia River Temperature Simulation . . . . . . 27

19 Temperature Excess Surface for Case 1: 1000 MW Plant at River Mile 78 , No Plant at River Mile 72.8 . . . . 30

20 Temperature Excess Surface for Case 2: $2000 \mathrm{MW} \mathrm{Plant}$ at River Mile 78 , No Plant at River Mile 72.8 . . . . 31

21 Temperature Excess Surface for Case 3: 1000 MW P1ant at River Mile 78, $1000 \mathrm{MW}$ Plant at River Mile 72.8 . . 32

22 Temperature Excess Surface for Case 4: 2000 MW P1ant at River Mile 78, 1000 MW Plant at River Mile 72.8

23 Temperature Excess Curves for Case 1: $1000 \mathrm{MW}$ Plant at River Mile 78, No P1ant at River Mile 72.8 
the estuarine VERSiON OF the COLHEAT digital Simulation MODEL

D. G. Daniels, J. C. Sonnichsen and R. T. Jaske INTRODUCTION

In order to predict the effects of dam and power plant construction on the temperature of rivers, in 1963 the Atomic Energy Commission Division of Production provided funding to the Pacific Northwest Laboratories to develop a river simulation temperature prediction system. The system conceived was a model based on continuity retaining enough flexibility to describe temporal and spatial variations of both thermal energy and mass in a moving fluid. (1) Originally developed to predict temperatures of the Columbia River, the model has proven its versatility in other river systems.(2-5) In addition, the flexibility of the COLHEAT river simulation system has recently been demonstrated by Jaske and Spurgeon in predicting the transport of radioactive iodine in the Columbia River. (6)

Because many power plants are presently on or planned to be located on estuarine portions of river systems, a simulation model was developed to examine their effects. This model, which is called the estuarine version and is the subject of this report, is a special purpose version of the basic COLHEAT system which allows for volume changes owing to stage variation resulting from tidal action. Homogeneity in the vertical direction has been assumed and, therefore, specific treatment of mixing across the halocline has not been included.

\section{SUMMARY}

As is necessary in the basic COLHEAT model (1-5) the estuarine version of the model requires that the flow as a function of time be specified at or within the system boundaries. The nature of flow within coastal plain estuaries requires that the following two ideas be implemented to achieve this capability: 
BNWL -1342

\section{MODEL DEVELOPMENT}

The major modifications of the existing COLHEAT model which were necessary to develop an estuarine version are described below.

\section{SPATIAL VARIATIONS IN FLOW}

The major physical difference of interest to this discussion between flow in rivers and flow in estuaries results from the influence of tides. Tidal activity causes variations in stage which produce changes in channel volume and variation in flow. To adapt the COLHEAT model for use in estuaries, one must be able to describe this stage variation and the accompanying flow variation as functions of time during the tidal cycle.

To do this the estuary is broken into river sections just as the river is broken into river sections in the COLHEAT model. However, in the estuarine river section, volume changes associated with changes in stage are used to determine changes in flow. Figure 1 shows a typical river section in plan view. The model is based on a single equation for mass conservation within a river section:

$$
q_{i-1}(t)=q_{i}(t)+\frac{d v_{i}(t)}{d t}
$$

where

$$
\begin{aligned}
q_{i-1}(t)= & \text { flow into the } i^{\text {th }} \text { river section } \\
q_{i}(t)= & \text { flow out of } i^{\text {th }} \text { river section } \\
\frac{d v_{i}(t)}{d t}= & \text { change in volume of } i^{\text {th }} \text { river section } \\
& \text { with respect to time. }
\end{aligned}
$$

Because all river sections presently used in the estuarine versions are right rectangular prisms, the change in volume with respect to time can be represented as a change in river stage. 


$$
\frac{d V_{i}(t)}{d t}=L_{i} w_{i} \frac{d S_{i}(t)}{d t}
$$

where $L_{i}=1$ ength of $i^{\text {th }}$ river section

$w_{i}=$ width of $i^{\text {th }}$ river section

$$
\begin{aligned}
\frac{d S_{i}(t)}{d t}= & \text { variation in river state with respect to time } \\
& \text { for } i^{\text {th }} \text { river section. }
\end{aligned}
$$

Substituting Equation (2) into Equation (1) yields

$$
q_{i-1}(t)=q_{i}(t)+L_{i} w_{i} \frac{d S_{i}(t)}{d t}
$$

Therefore, by knowing the flow as a function of time at or within the system boundary and the variation in river stage with respect to time for each river section, Equation (3) can be used to describe the flow in an estuary. Figures 2 and 3 are system flow charts which depict the flow of information for the stage and flow calculations respectively.

\section{WATER TRANSPORT}

In programming flow through an ordinary river system, allocating flow from one river section to the next is simple if river sections are assumed to maintain constant volume, and flow is always downstream and constant with respect to distance downstream. However, the problem is not so simple when simulating estuaries. Not only can estuary river section volumes change so that flow into a river section is not equal to flow out of that river section, but also the flows can change direction and actually be directed upstream during portions of the tidal cycle. Thus, allocating flow in an estuarine river section becomes more complicated. Figure 4 shows the four possible cases and governing equations. Flow is defined as positive downstream; negative upstream. Figures 5 through 11 show the transport flowchart. 
BNWL- 1342

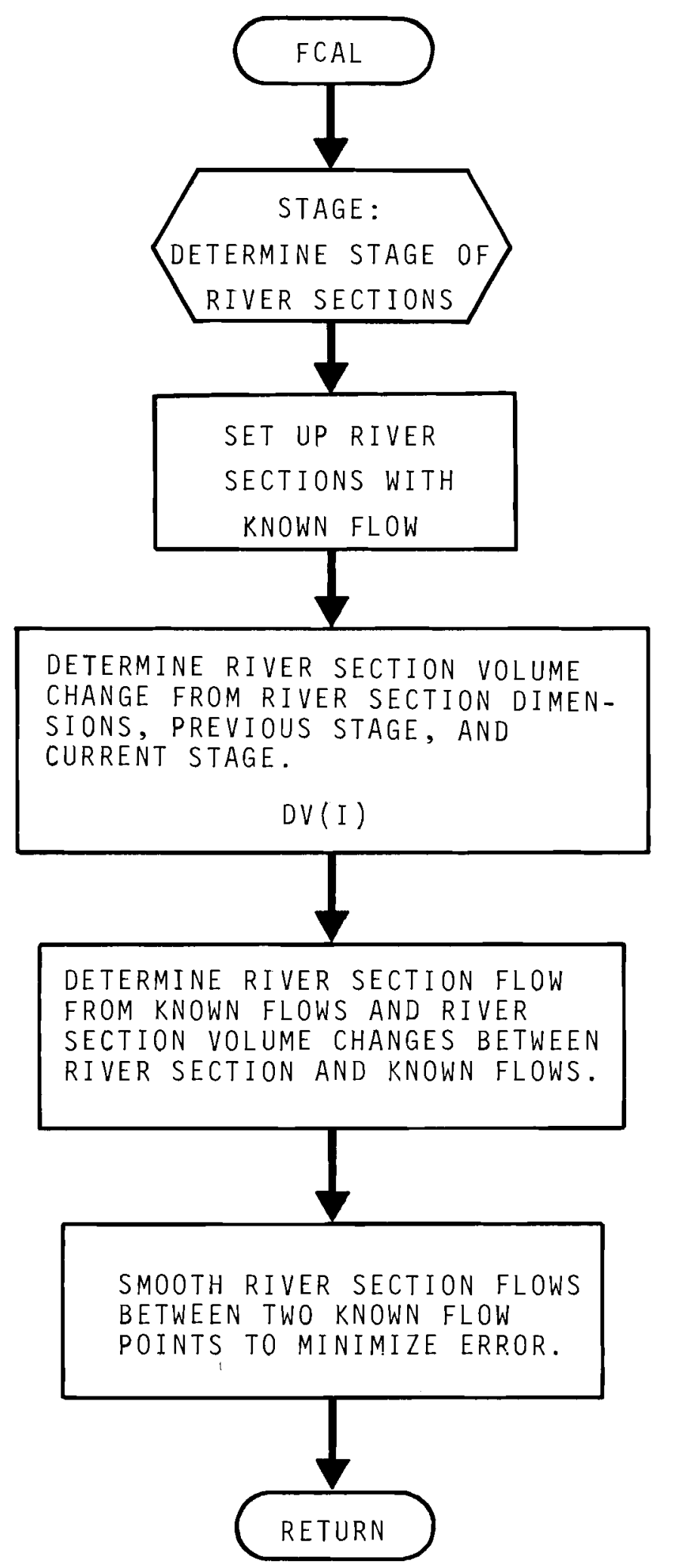

FIGURE 3. Flow Calculation Flow Chart for Estuarine Version 
BNWL- 1342

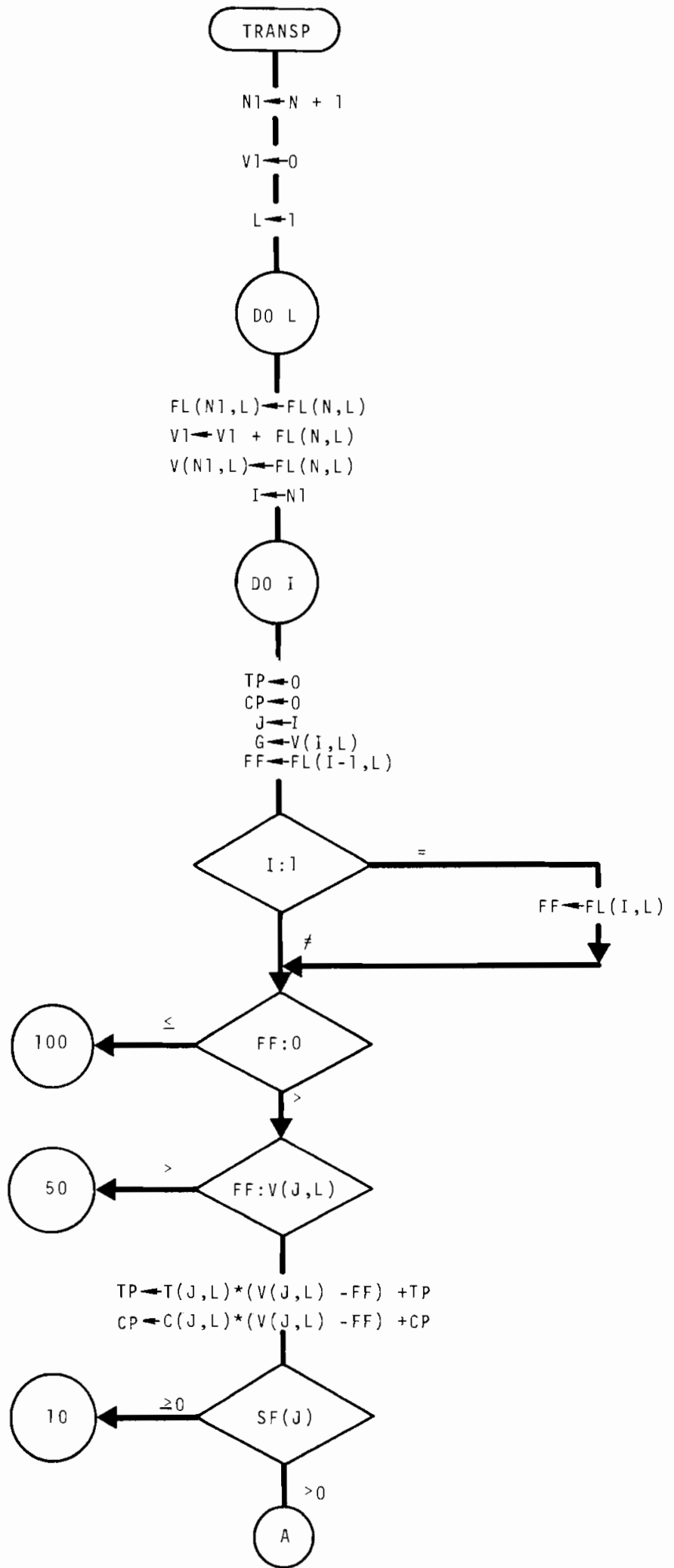

FIGURE 5. Flow Chart for Water Transport --Initiation for $\mathrm{n}$ Trough Flow 
BNWL -1342

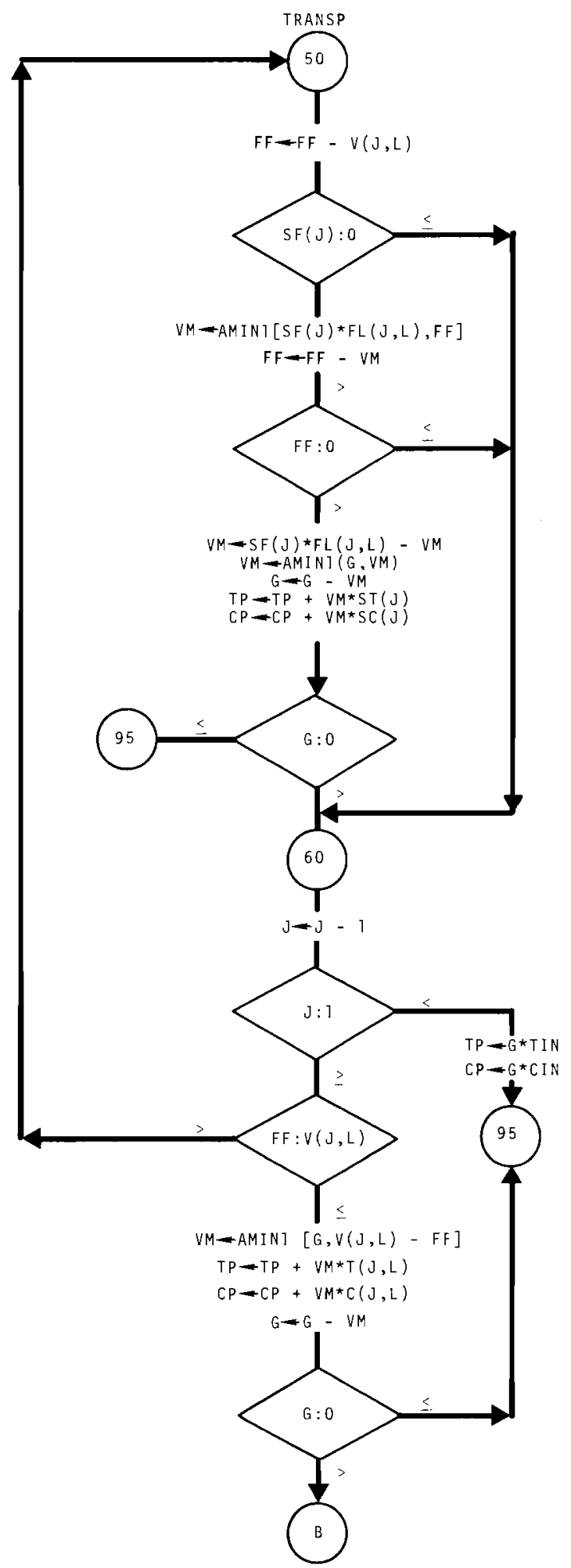

FIGURE 7. Flow Chart for Water Transport --High Flow 
BNWL -1342

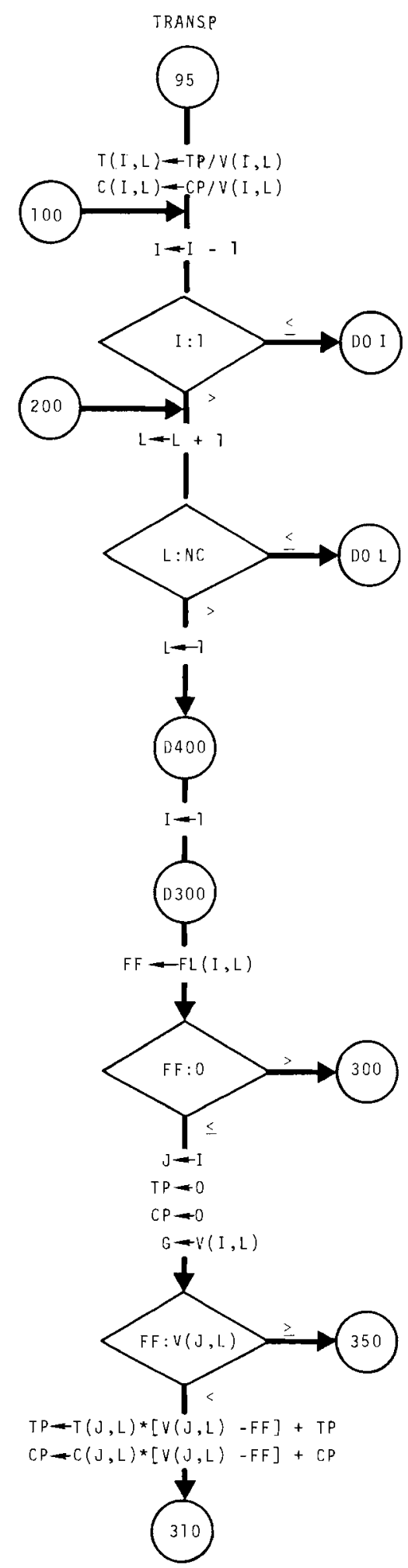

FIGURE 9. Flow Chart for Water Transport --Complete Normal Flow and Check for Reverse Flow 
BNWL -1342

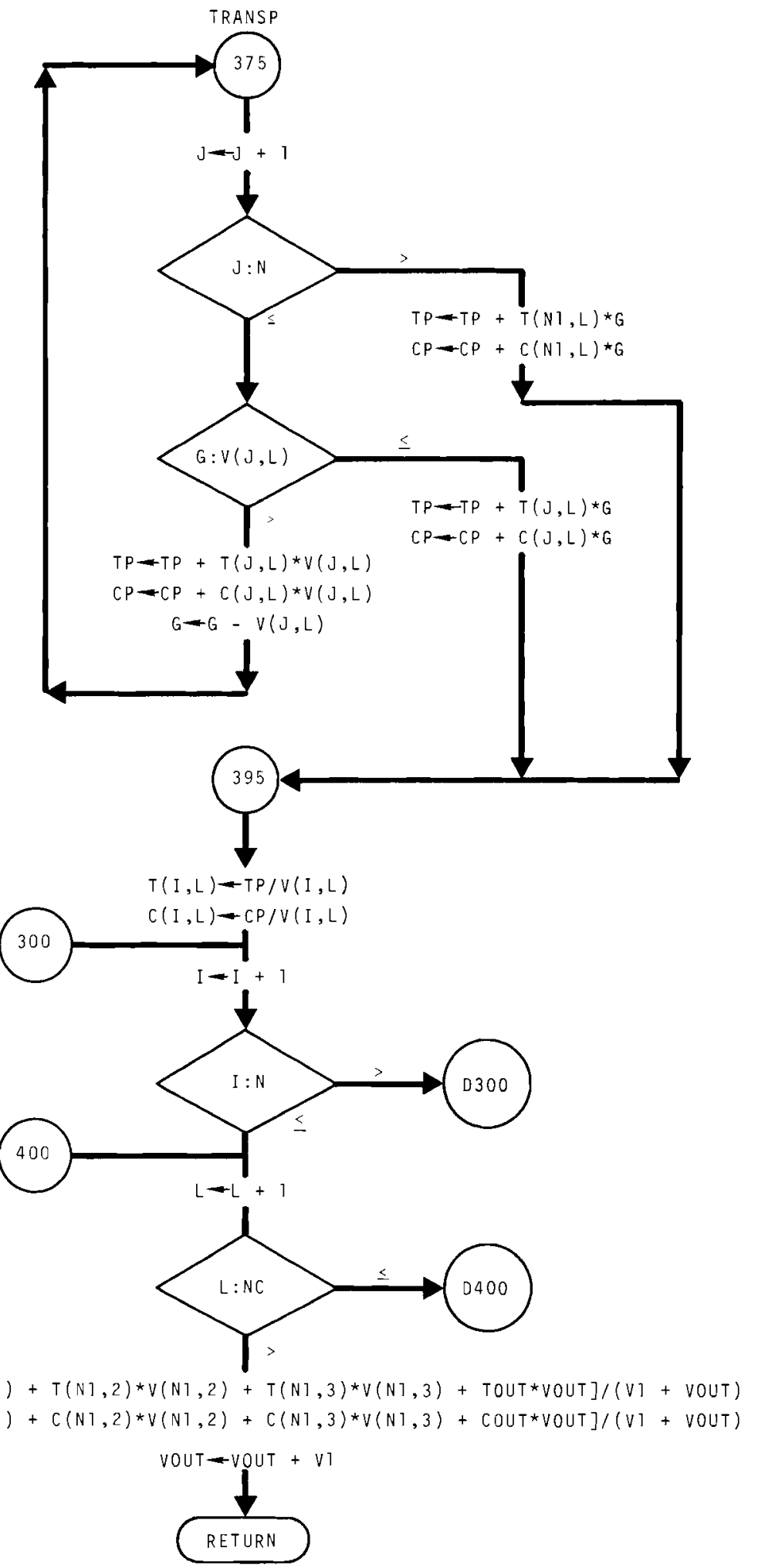

FIGURE 11. Flow Chart for Water Transport -- Reverse Flow - River Section Values and Terminal Values 
BNWL -1342

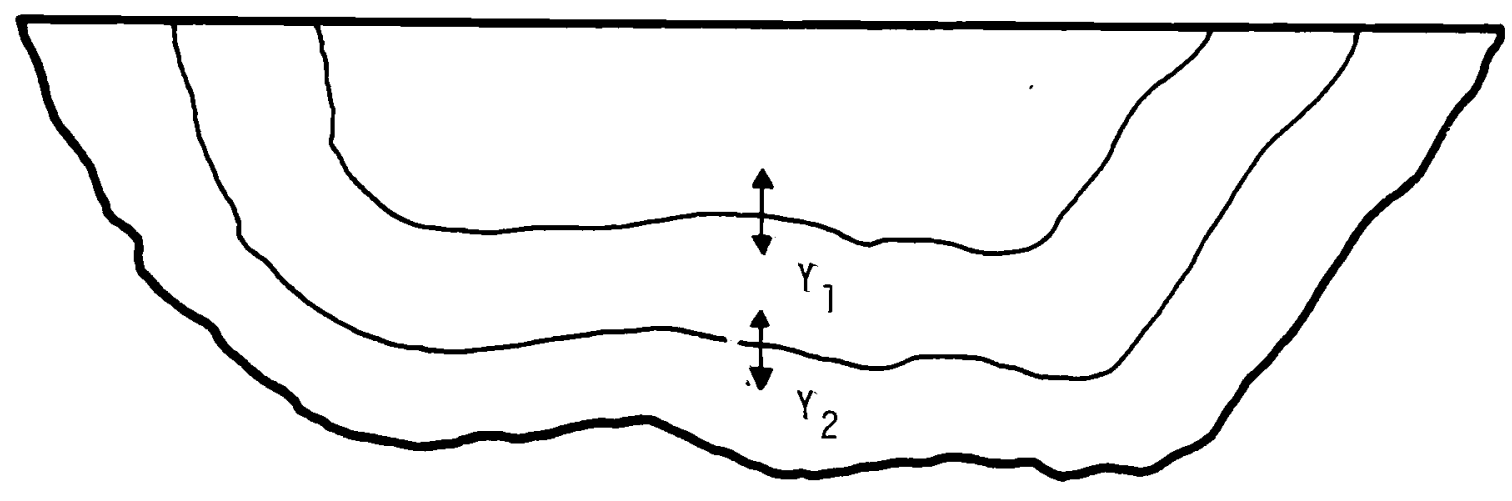

$$
\begin{aligned}
& A P_{1}=A_{1}\left(1-y_{1}\right)+A_{2} y_{1} \\
& A P_{2}=\frac{\left[A_{1} y_{1} V_{1}+A_{2}\left(V_{2}-y_{1} V_{1}-y_{2} V_{3}\right)+A_{3} y_{2} V_{3}\right]}{V_{2}} \\
& A P_{3}=A_{2} y_{2}+A_{3}\left(1-y_{2}\right)
\end{aligned}
$$

FIGURE 12. Partial Mixing Concept for Mixing in the Three-Trough Model 
BNWL -1342

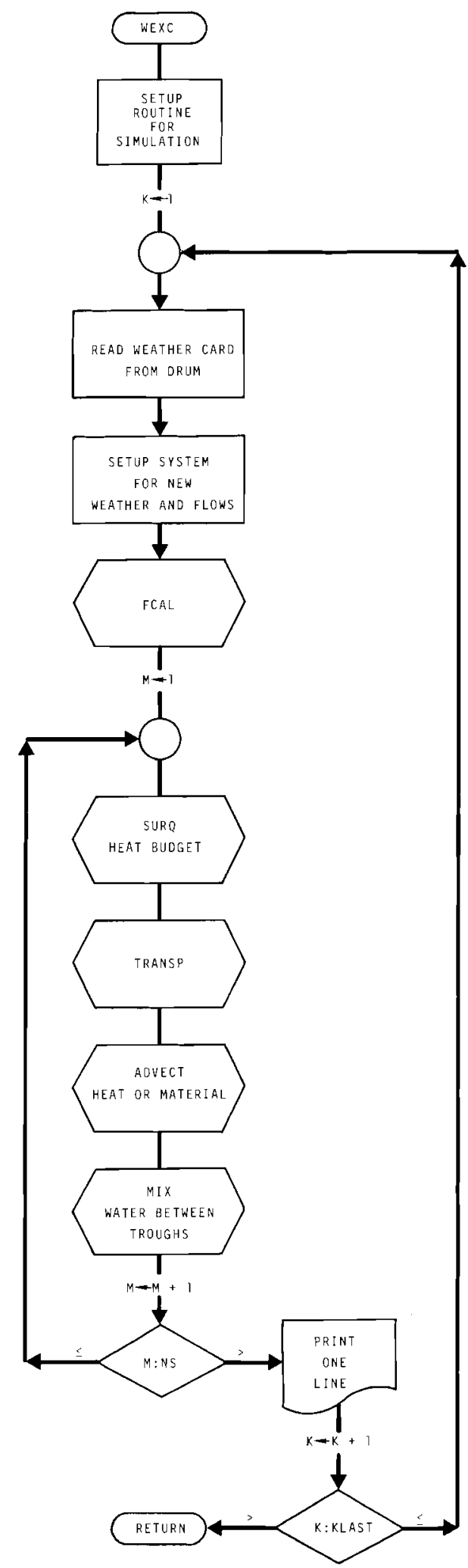

FIGURE 13. Structure of Executive Program for the Estuarine Version 
BNWL- 1342

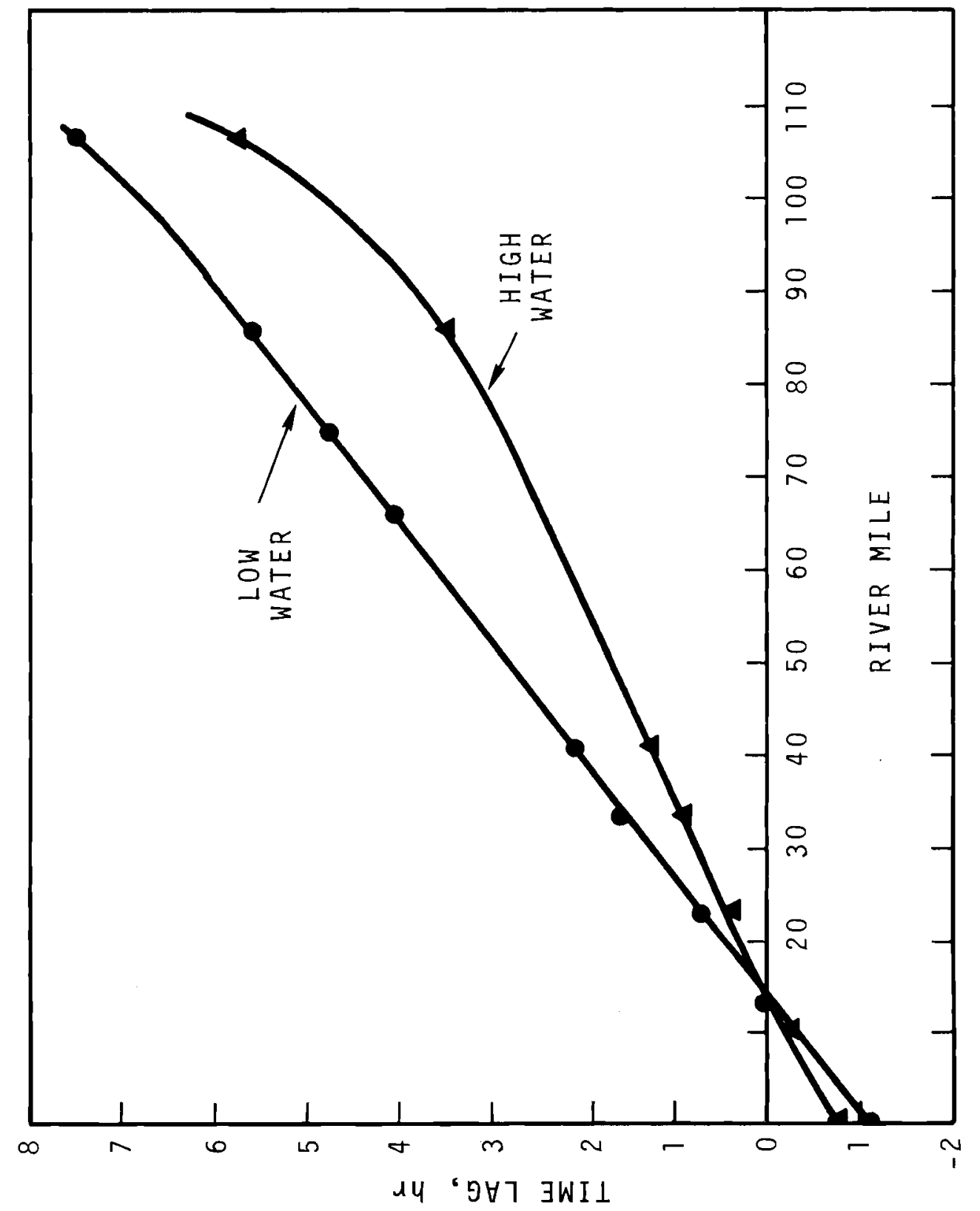

幽急品

○ 9

田要

E

吊

द्व

4 N

0

品

ह5

उEU

듐

"ृ

ब

工苗 क

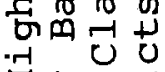
两 400

$4 \stackrel{1}{5}$

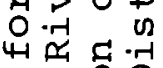

का 万人

a.

그 0 o

(를

हनㄱㄷㅐ

-

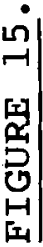


BNWL - 1342

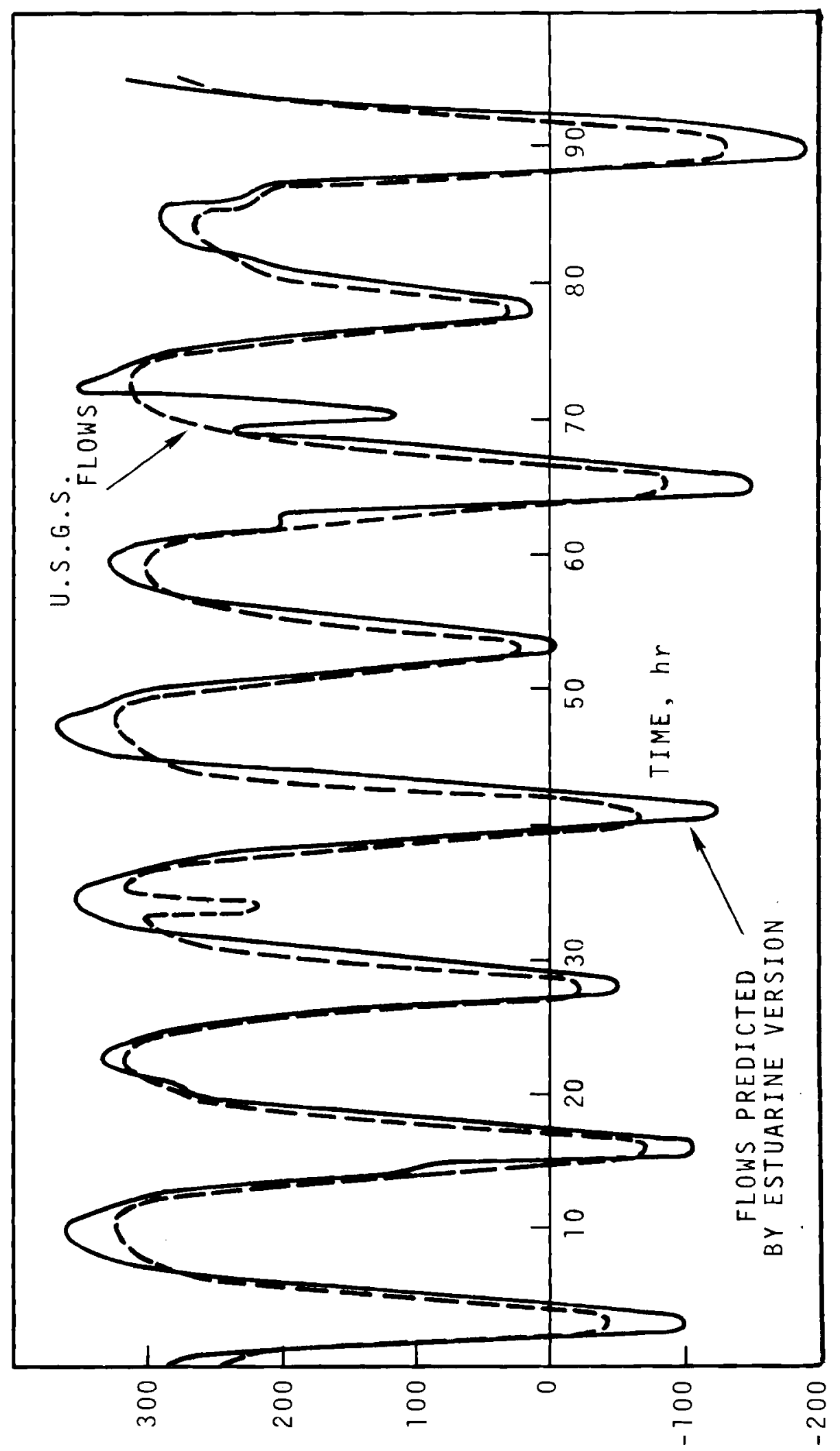

岁 烍

मे प्र

(1) 51

मे० 0

药 $4-15$

영다 넝

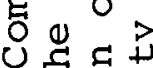

पै 0.7

म4.

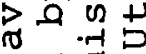

(1) 品

क 040

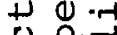

क

각ำ

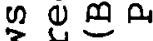

कि

我我

4 20

4 范?

せ

$>$ 质

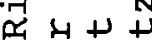

(1) त.

- $>\quad r$

? 丢

0 U

- c 0

ज䒠

๑

吕

$\varepsilon^{0 L} \times$ SHJ 'MOTH 
Temperature is assumed to follow the same mixing relationship and when good simulation is obtained in the concentration mode, the model using the same partial mixing coefficients is applied to the temperature mode. The appropriate values for both partial mixing coefficients are assumed to be equal and for this reach of the Columbia under steady flow conditions are:

$$
y_{1}=y_{2}=0.0065
$$

Figure 12 on page 17 has the definition of the partial mixing coefficients $y_{n}$.

TEMPERATURE SIMULATION

Temperature simulations were run for the two 5 day periods of August 8 through 12, 1967, and September 2 through 6, 1967. Calculated temperatures were compared for both periods with observed temperatures at Beaver, and for the latter period at Longview (River Mile 66.0). Figures 17 and 18 illustrate the quality of the simulation.

Because of sloughs located along the Oregon shore, temperatures at the Beaver Army Terminal are consistently about $0.4^{\circ} \mathrm{C}$ higher than the average transect temperatures during the summer months. Therefore, if $0.4{ }^{\circ} \mathrm{C}$ is subtracted from the observed Beaver temperature curve, good agreement is obtained between the Beaver observed and Beaver calculated temperatures.

\section{CASES EXAMINED}

The estuarine version for the cases examined extended from St. Helens to the lower end of Puget Island (River Mile 37.6). River sections $1000 \mathrm{ft}$ long employing the partial mixing concept were used to simulate the reach between 


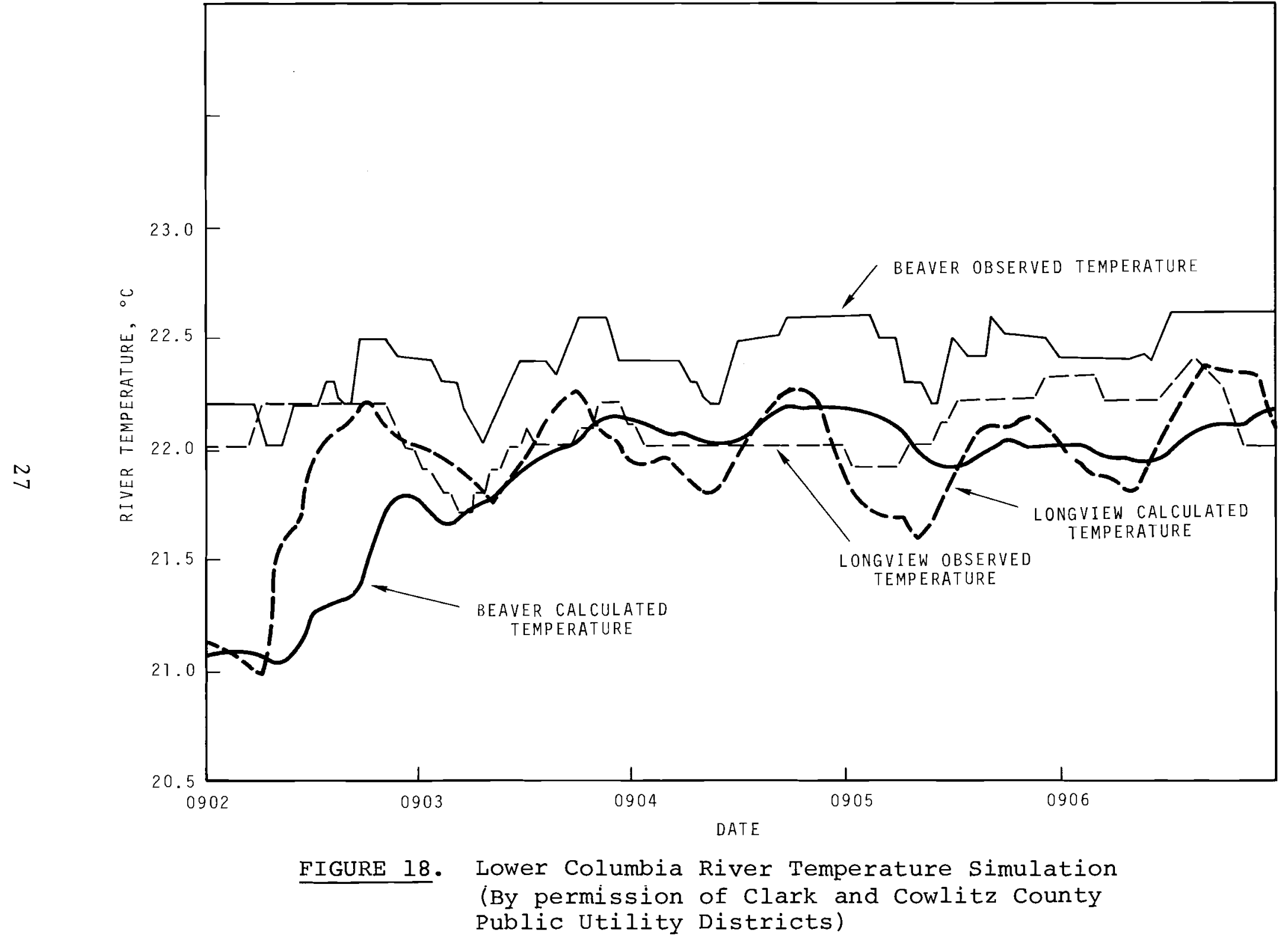




\begin{tabular}{|c|c|c|}
\hline Case & Plant Genera & ng Capacity, MW \\
\hline No. & River Mile 78 & River Mile 72.8 \\
\hline 1 & 1000 & 0 \\
\hline 2 & 2000 & 0 \\
\hline 3 & 1000 & 1000 \\
\hline 4 & 2000 & 1000 \\
\hline
\end{tabular}

Temperatures for all runs were recorded every hour at selected river mile locations. These temperatures were an average for the water volume through a given river cross section every hour. Then the temperature excesses, that is, temperature differences between the case with no advected heat (natural conditions) and one with advected heat, were calculated for each case ever hour and at each of the following river miles:

$\begin{array}{ll}79.4 & 72.6 \\ 78.5 & 71.8 \\ 77.9 & 70.7 \\ 78.0^{*} & 69.7 \\ 77.5 & 68.3 \\ 76.6 & 67.2 \\ 75.4 & 66.0 \\ 74.1 & 53.5 \\ 73.0 & 46.0 \\ 72.8^{*} & 38.0\end{array}$

* Prant Site

Figures 19 through 22 show these temperature excesses, plotted by computer, for Case 1 through Case 4 for the second 5 day period. The horizontal axis represents time in days, the vertical axis represents the temperature excess in degrees centigrade, and the oblique axis at $30^{\circ}$ to the horizontal represents distance upstream from the mouth of the Columbia 
BNWL - 1342

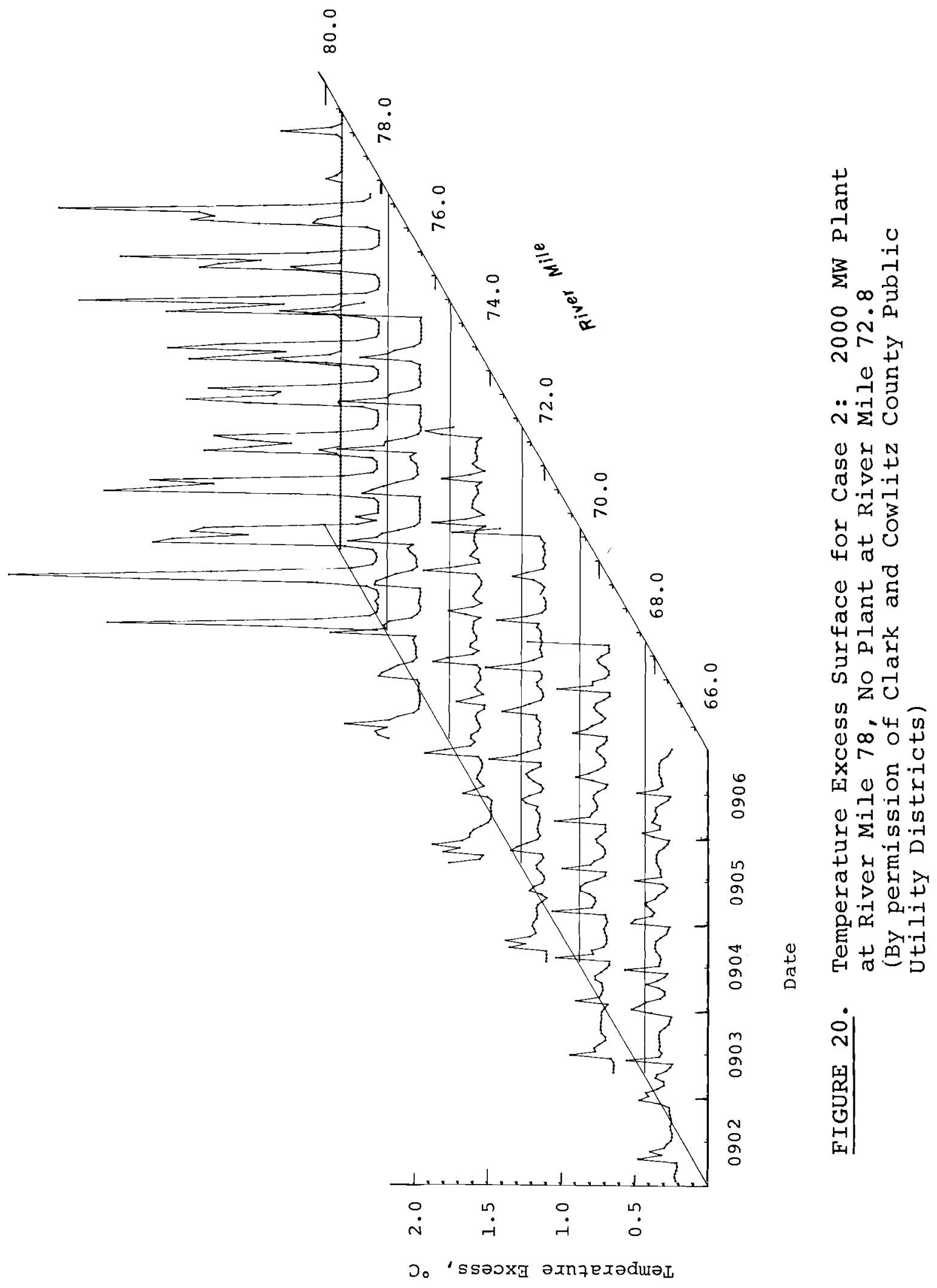




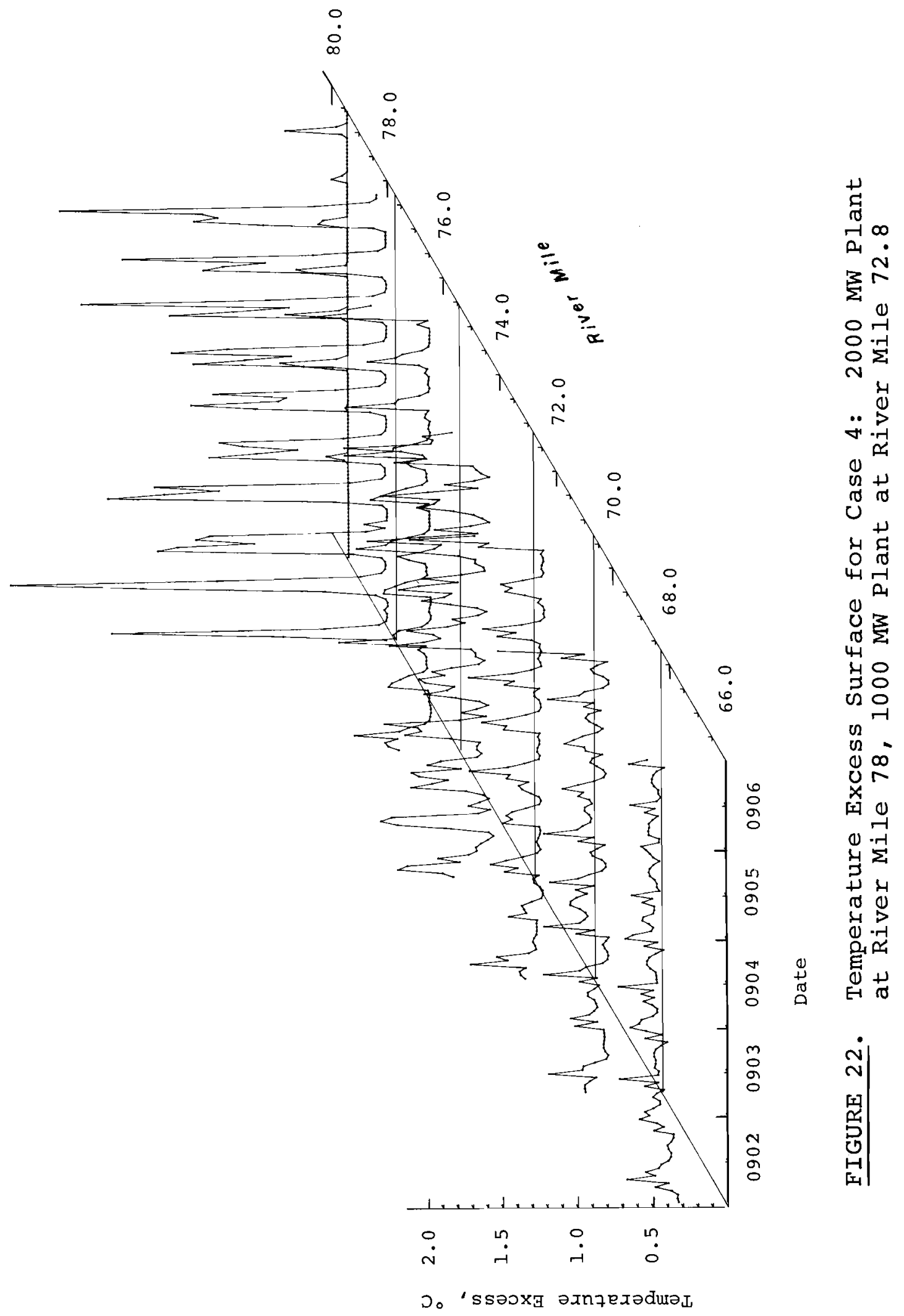


BNWL - 1342

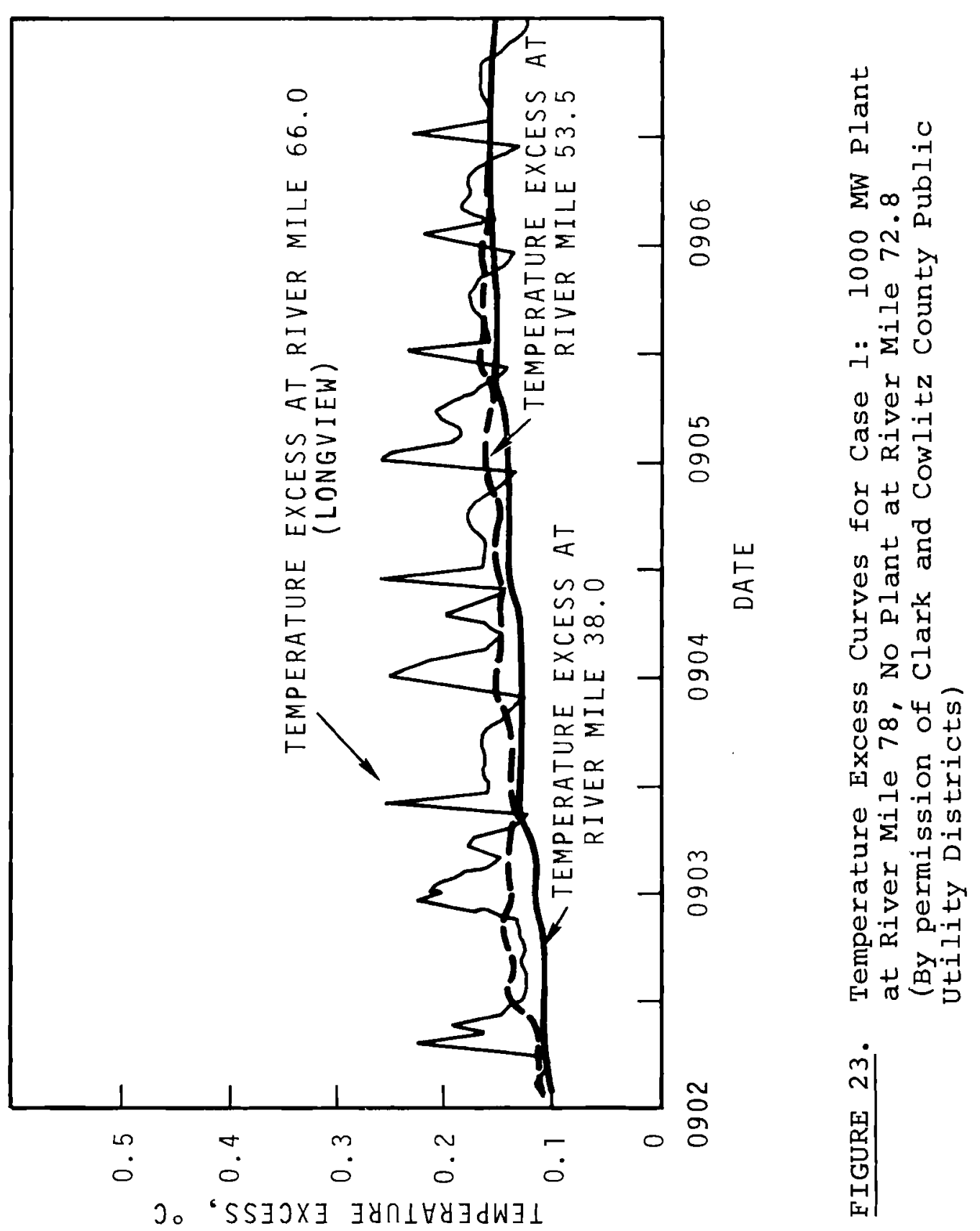


BNWL -1342

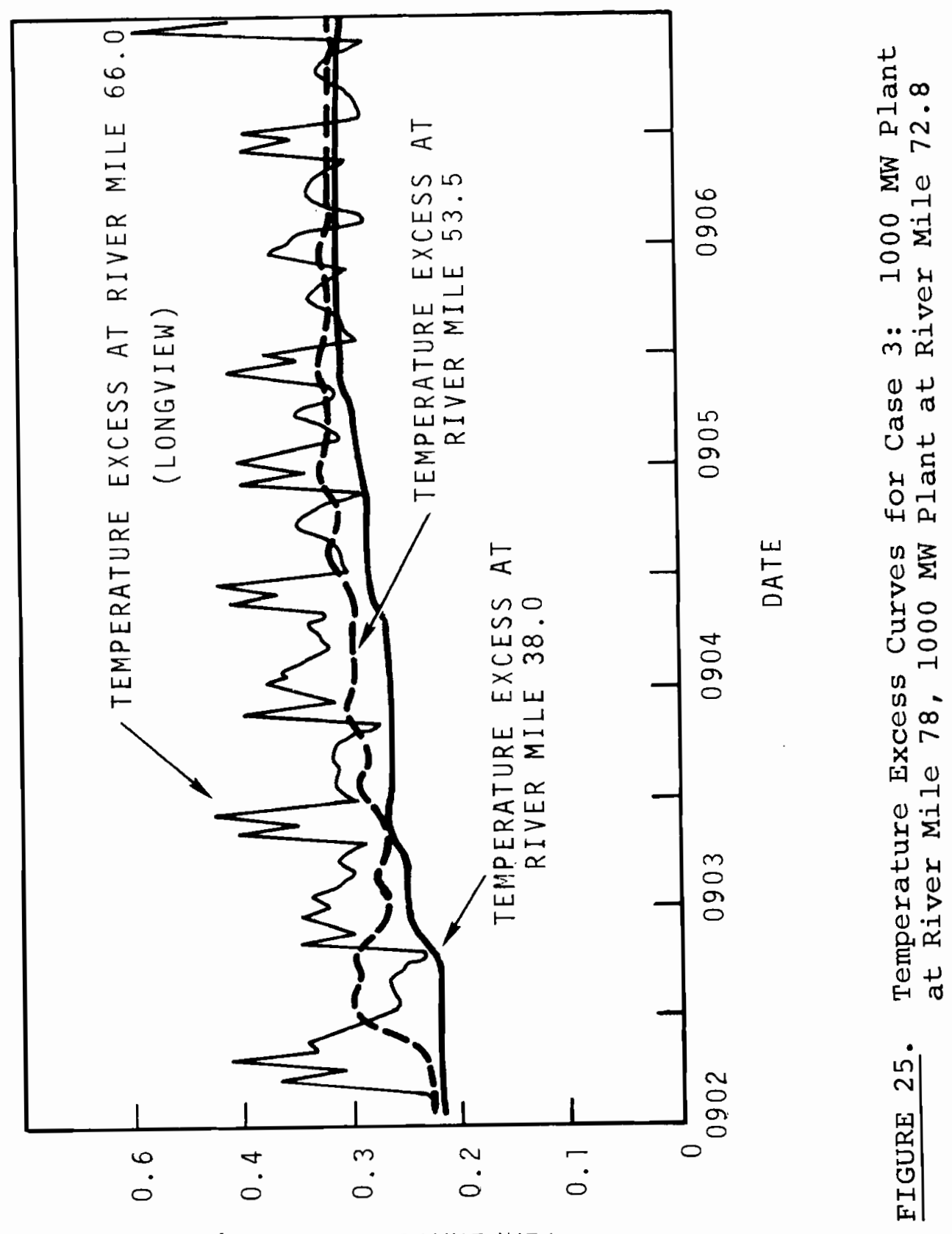

ว。‘ SS $\exists J \exists \exists \exists y \cap \perp \forall y \exists d W \exists \perp$ 


\section{ACKNOWLEDGMENT}

The authors wish to thank Jesse L. Spurgeon of Computer Sciences Corporation for his key role in the physical programming and operational testing of the various versions of COLHEAT. Figures 2, 3, 5 through 11 , and 13 were prepared by $\mathrm{Mr}$. Spurgeon in the course of documentation of the estuarine version.

The authors are a1so grateful to Portland General Electric for loaning equipment and personnel during dye tests, for servicing thermograph installations, for taking an active role in encouraging the exchange of field data collected in the particular river reach, and for providing the valuable general assistance of $\mathrm{J}$. Aldersebaes; Port of Kalama for granting to Battelle-Northwest the use of their facilities during the dye tests; Bureau of Commercial Fisheries for receiving and storing materials, and for providing to the various assigned river craft the use of their launching facilities; and Clark and Cowlitz County Public Utility Districts for their assistance in funding of field studies relative to development of the estuarine version. The field conditions described are adapted from a report prepared to support a potential site. 


\section{DISTRIBUT ION}

$\frac{\text { No. of }}{\text { Copies }}$

177

16
AEC Chicago Patent Group

$$
\text { G. H. Lee }
$$

AEC Division of Technical Information Extension

AEC Library; washington Division of Reactor Development and Technology

W. G. Belter

I. C. Roberts

M. J. Whitman

Division of Intelligence

C. H. Reichart

Division of Isotope Development

R. Butinhoff

Division of Operational Safety

A. A. Schoen

Division of Biology and

Medicine

John Wolfe

1 AEC Nevada Operations Office Effects Evaluation Division

J. J. Davis,

Scientific Deputy

1 American Institute of Chemical Engineers 900 W. Orange Grove Road Tucson, Arizona 85704

Lawrence Cecil

1 Atomic and Space Development Authority 230 Park Avenue New York, N. Y. 10017

J. G. Cline

1 Atomic Energy of Canada Limited Chalk River Nuclear Laboratories Chalk River, Ontario, Canada

J. C. Biggs

1 Benton County Pub1ic Utility District No. 1 524 South Auburn Street P. O. Box 6270 Kennewick, Washington 99336

Thomas E. Black, Manager
No. of

Copies

3

Bonneville Power Administra-

tion

$\overline{1002}$ N. E. Ho11aday

Portland, Oregon 97208

F. A. Limpert

W. L. Morse

E. C. Starr

1

British Columbia Hydro

and Power Authority

970 Burrard Street

Vancouver, B.C., Canada

T. F. Daggs

1 Central Nebraska Public Power and Irrigation District P. O. Box 356 Holdrege, Nebraska 68949

E. L. Hami1ton

W. Hickok

T. Johnson

1 Chelan County Public Utility District

(Rocky Reach Dam) 327 North Wenatchee Avenue Wenatchee, Washington 98801

Howard C. Elmore, Manager

1 Chelan County Pub1ic Utility District

P. O. Box 1231

Wenatchee, Washington

J. H. Schrengohst

1 Clallam County, PUD No. 1 P. O. Box 951

Port Angeles, Washington 98362

M. D. Parrett

2 Clark County Public Utility District

1200 Fort Vancouver Drive Vancouver, Washington 98663

F. H. Lehman

George W. Watters, Manager

1 Colorado River Board

State of California

909 South Broadway

Los Angeles, California 90015

H. F. Pellegrin

1 Computer Sciences Corporation

J . L. Spurgeon

Distr-1 
BNWL -1342

No. of

Copies

1

Foundation of Canada Engineering Corporation Limited

2200 Yonge Street

Toronto 12 , Canada

H. R. Kivisild

1

Governor's Science Resource Advisory Board

State Office Building

Annapolis, Maryland 21401

L. W. Fredrick

1

Grant County Public Utility District

(Wanapum and Priest Rapids Dams )

30 C Street, S.W.

Ephrata, Washington 98823

E. R. Ries

1 Great Lakes Basin Commission

Ann Arbor, Michigan 48105

L. T. Crook

1 Illinois State Water Survey Champaign, Illinois

W. C. Ackermann

1 International Joint Commission

Chairman, U.S. Section

Washington, D.C. 20000

M. E. We 1 sh

1 Manhattan College

Parkway and West 242 nd

New York, New York 10000

D. J. O'Connor

1 Metropolitan Sanitary

District of Greater Chicago

100 East Erie Street

Chicago, Illinois 60611

V. A. Bacon

1 NAPCA, Division Process

Control Engineer

5710 Wooster Pike

Cincinnati, Ohio 45227

R. P. Hangebrouck

1 New York State Department

of Conservation

A1bany, New York

N. L. Barbarossa

1 New York State Department

of Health

84 Holland Avenue

Albany, New York

L. G. Het1ing
No. of

Copies

1

Northwest Public Power

Association

Vancouver, Washington 98660

Fenry Curtis, Manager

2 Oak Ridge National Laboratory

Building 9201-3

P. 0. BOX Y

Oak Ridge, Tennessee 37830

S. E. Beall, Jr.

M. M. Yarosh

1 Ontario Water Resources

Commission

801 Bay Street

Toronto, Ontario, Canada

W. A. Stegg1es

1 Pacific Northwest River

Basins Commission

Trans American Tile Company

Building

110 E. 13th street

Vancouver, Washington 98661

Donel Lane

2 Pacific Power and Light

Public Service Building

Portland, Oregon 97204

E. B. Hedberg

R. B. Lisbakken

1 Pend Oreille County Public

Utility District

(Box Canyon Dam)

$130 \mathrm{~N}$. Washington Avenue

Newport, Washington

George Kennett, Manager

1 Philadelphia Electric Company 1000 Chestnut Street

Philadelphia, Pennsy1vania 19105

J. L. Everett

1 Philips Petroleum Company

Atomic Energy Division

Idaho Falls, Idaho

W. L. Slagle

2 Portland General Electric

621 S.W. Alder

Portland, Oregon 97205

A. J. Porter

L. E. Hode 1 


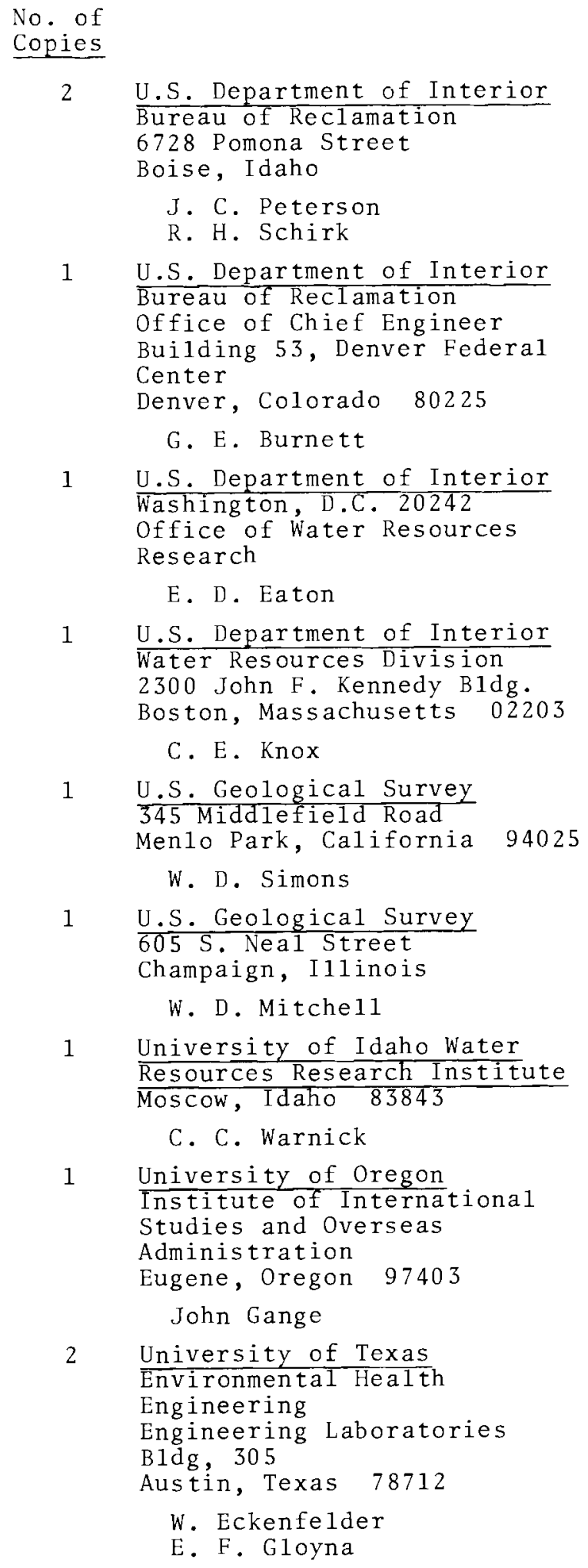

U.S. Department of Interior Bureau of Reclamation 6728 Pomona Street

1 U.S. Geological Survey 345 Middlefield Road Menlo Park, California 94025

W. D. Simons

1 U.S. Geologica1 Survey

605 S. Neal Street

Champaign, I11inois

W. D. Mitche 11

1 University of Idaho Water Resources Research Institute Moscow, Idaho 83843

C. C. Warnick

1 University of Oregon

Institute of International

Studies and Overseas

Administration

Eugene, Oregon 97403

$$
\text { John Gange }
$$

2 University of Texas

Environmental Health

Engineering

Engineering Laboratories

B1dg, 305

Austin, Texas 78712
W. Eckenfelder
E. F. Gloyna

No. of

Copies

1

University of Western Ontario London, Ontario, Canada

E. G. Pleva

1 University of WisconsinMilwaukee

Center for Great Lakes Studies

Milwaukee, Wisconsin 53201

C. H. Mortimer

1 University of Wyoming

Laramie, Wyoming 82070

F. Trelease

1 Vanderbilt University

Dept. of Environmenta 1 and Water Resources Eng.

Nashville, Tennessee

37203

F. L. Parker

$1 \quad$ Virginia Electric

and Power Company

Richmond, Virginia 23201

J. D. Ristroph

1 Washington Department

of Fisheries

General Administration B $1 \mathrm{dg}$. Room 115

Olympia, Washington 98501

E. H. LeMier

1 Washington Public Power

Supp1y System

132 Vista Way

Kennewick, Washington 99336

Owen Hurd, Manager

1 Washington State Department of Health

Olympia, Washington

E. C. Jensen

2 Washington State Department of Water Resources

$\overline{3} 35$ General Administration B1dg.

Olympia, Washington 98502

Maurice Ah1quist

Fred Hahn

1 Washington State Pollution Control Commission

P. O. Box 829

Olympia, Washington 98502

George Hansen 